\title{
Ways to Translate a Newly-Introduced Concept
}

\author{
Cong Liao* \\ The Key Project Center of Anhua County, Anhua 413500, Hunan Province, China
}

*Corresponding author: Cong Liao, 2780759923@qq.com

\begin{abstract}
Translation is a complicated thinking and a practicing process, which involves many theories and skills. According to the theory of dynamic equivalence and based on literature studies as well as personal practical experiences, three viewpoints have been proposed in this article to discuss on how to translate a newly-introduced concept; namely, giving full consideration to the meaning of newly-introduced concepts, paying attention to the evolution of the concepts, and seeking for a similar meaning in the traditional classics of a nation, each of which is exemplified in order to facilitate understanding.
\end{abstract}

Keywords: Dynamic equivalence; Translation; Newly-introduced concept; Evolution of a concept; Classics

Publication date: December 2021; Online publication: December 23, 2021

\section{Introduction}

Eugene A. Nida, a prominent American translation theorist, once defined translation as a reproduction of the closest natural equivalent of the source-language message in the receptor language; first, in terms of meaning, and secondly, in terms of style ${ }^{[1]}$. According to Dr. Nida's definition, equivalence, not static but dynamic, is the highest pursuit of and the most ideal level of translation. However, it is always a pity that a translated work and its original cannot be deemed as absolute equivalent ${ }^{[2]}$. When a translator is translating a newly-introduced concept, the phenomenon is likely to become more striking. Aimed at such a problem, this paper tries to provide methodological solutions to arrive at an appropriate term for a newly-introduced concept, according to the theory of dynamic equivalence and based on literature studies as well as personal practical experiences. There are three viewpoints raised in the article, which give full consideration to the meaning of a newly-introduced concept to avoid mistranslation or one-sided translation, paying attention to the evolution of the concept to make its target and source texts synchronically equivalent, seeking for similar meanings in the traditional classics of a nation, and never separating cultural linkages, each of which is expounded in the following contents.

\section{Giving full consideration to the meaning of a newly-introduced concept to avoid mistranslation or one-sided translation}

In some cases, translations have exerted huge social influence on a nation. For example, confronted with a serious national crisis caused by a series of aggressions brought on by Western powers, many Chinese patriots with lofty ideals began to learn science, technology, politics, etc. through the translation of Western works in these areas for the goal of safeguarding and prospering China, thus leading to the broad spread of Western learning among the Chinese official and intellectual classes; consequentially, they were enlightened to drive movements for self-strengthening and prosperity. However, at times, translators could not find the proper expressions for various new concepts in the process of translating Western works, which trouble them tremendously. In confrontation of such troublesome situations, the only way to solve them is to create new phrases to fill in the blanks. This compelled practice, consisting of a careful semantic analysis 
of "lexico-grammatical features of immediate unit, discourse context, communicative context, cultural context of the source language, and cultural context of the receptor language ${ }^{[2]}$," is quite demanding and the process can be awfully hard. Especially in translating influential works, if a translator fails to grasp the overall meaning of the key concept and attaches with it an improper or one-sided translated term, such a translation would bring about a negative social impact, which could be irreversible. The following discusses a widely known example in the Chinese translation history.

The word "rights," which is defined as "something to which one has a just claim" in the MerriamWebster Dictionary, is a judiciary and social concept, which was introduced to China in the late 19th century and of significance for the development of China's democracy. At that time, many sophisticated scholars, both domestic and foreign, published their translations of this newly-introduced concept. The first to publish the formal translation of "rights" is an American Protestant missionary, William Alexander Parson Martin (丁韪良), who served as the Vice President of the Imperial University of Peking, the predecessor of Beijing University. In 1862, when Martin was translating Elements of International Law by an American jurist, Henry Wheaton, he selected the phrase “权利” as the translation of "rights," though he was not very satisfied with it. However, this brand-new concept had not drawn much attention from the conservative and backward Qing dynasty then, but in contrast, it had appealed to Japan under the Government of Meiji. As a result, “权利” soon became popular in Japan. In the first Sino-Japanese war (1894-1895), China, the top power in the Far East in the 19th century, lost badly, which led to the rise of the Chinese people's national awareness and the Chinese patriots' willingness for learning. With a desire to understand why Japan grew, many patriots went to that country to learn the latest scientific and political fruits in a systematic manner through it. Coincidentally, “权利” returned to China at this time. When translating the Western works that had been published in Japanese, Liang Qichao (梁启超), a reputed Chinese thinker and statesman, retranslated the word into “权利.” Due to the rapid circulation of translated works by Liang Qichao as well as his unique influence on the Chinese academia, “权利” was eventually accepted as the standard translation of “rights.” However, as a matter of fact, “rights” and “权利” are distinguishably different in connotative meaning. From most Westerners' perspective, every human being is born with rights, in which it is heavengiven and inalienable. In contrast, “权利” in ancient China is rather negative and derogatory because it is often associated with exclusive interests and extreme individualism, reflecting a snatching action; moreover, ancient Chinese people regarded it as an opposition against righteousness, just as an old saying in Discourses on Salt and Iron (盐铁论·轻重) by Huan Kuan goes, "Righteousness and rites are the foundation of a country, while private ends can do harm to its authority” (礼义者，国之基也; 而权利者， 政之残也). Considering the possible negative impact of such a translation, Yan Fu, who was Liang's friend and comrade, wrote a letter in 1902 to inform him of the inappropriateness of the translation, saying, "Three years ago when I began to read Western political books, I found it very difficult to appropriately translate the word 'rights.' In my opinion, “权利’ is an arbitrary translation and may misguide social ethos” (仆前 三年, 始读政理诸书时, 即苦此字无译, 强译 ‘权利” 二字, 是以霸译王, 于理想为害不细). In review of the later generations' reactions to “权利,” it is clear that Yan Fu's worry is not groundless ${ }^{[3]}$. On one hand, the translation of “权利” may lead to a cultural shock and an illusion, which makes human rights look like a purely imported element and have nothing to do with ancient China. In fact, human rights are heaven-given and every individual on earth is entitled to enjoying them; rights are thus a universal and cosmopolitan matter that Chinese ancestors had attained a rough knowledge about but had not held on to before. In translating the word "rights," the more sensible way is to seek for an indigenous expression from Confucian classics, which may help to localize the new concept (this viewpoint is further discussed in the last part of this section and Section 2). On the other hand, “权利” is the homophone of another phrase “权 力.” Liang's translation may result in ambiguity among Chinese people to understand from both cognitive and practical aspects. In feudal China, all powers were concentrated in the royal government. As a 
consequence, ordinary Chinese people had little awareness of democracy and the rule of law. The concepts of “权利” and “权力” are so easily confused that this brings obstacles to increasing the awareness of democracy and rule of law. For the translation of "rights," it may be more feasible to translate the word into “权益,” considering that the character “益” has a positive meaning of "benefits or benefiting."

\section{Seeking for similar meanings in a nation's traditional classics and never separating cultural linkages}

Diachronically speaking, a nation's traditional cultures, philosophies, and ethics, which are documented in ancient classics, have lasting influence on its development. For example, the fundamental Confucian thoughts in the Four Books and Five Classics (四书五经) had been the emphasis in the Chinese society for almost two thousand years; synchronically, by comparing the major human civilizations horizontally, one may find that they have many things in common, which are commonly known as "universal values" by scholars; this means that different nations may hold similar understandings on certain issues. Accordingly, a translator can consult his or her nation's classics to seek for similar meanings for a newly-introduced concept for the purpose of equivalating a translation to its original, thus meeting the requirements of cultural coordination in accordance with the theory of dynamic equivalence raised by Dr. Nida ${ }^{[2]}$. Translating $\Sigma \tau o l \chi \varepsilon i \tilde{\alpha}$ (hereinafter, referred to as Elements of Geometry) is a good example to illustrate this point.

In 1600, Matteo Ricci, a reputed Italian Catholic missionary and early sinologist, began to systematically introduce scientific findings and technological fruits from the Western world to Chinese scholar-officials after settling in Beijing, the capital of the Ming Empire. Xu Guangqi, a renowned Catholic believer, scientist, and statesman, who passed the palace test and was admitted to the Royal Academy in 1604, often visited Ricci to enquire about Catholic doctrines and the scientific knowledge at that time. Meanwhile, Ricci appreciated Xu's talent. When coming across Elements of Geometry by the ancient Greek mathematician Euclid, $\mathrm{Xu}$ realized that it is significant to the scientific development of China and highlighted this by saying, “Geometry is very conducive to acquiring scientific knowledge” (几何之学, 深有益于致知). In consideration of the significance of the book, he therefore tried to persuade Ricci to cotranslate it, which in turn was a success. In the process of translating the book, Ricci described the contents using his good mastery of Chinese, while Xu recorded and modified what Ricci had said. In pursuit of the most accurate translation, they repeatedly collated their drafts. Unfortunately, Ricci passed away in 1607. As a result, the translation work had to be suspended, with only six chapters completed. However, their work has made a great contribution to China's scientific development. The work was eventually completed by a Chinese mathematician, Li Shanlan (李善兰), and a British Protestant missionary and sinologist, Alexander Wylie (伟烈亚力), in 1857.

"Magnitudus" is one of the core concepts in Elements of Geometry, which means "magnitude" or "quantity." When translating this word, Xu consulted plenty of traditional Chinese classics and made much deliberation. Finally, he assumed the term “几何” as the translation of “magnitudus." It is notable that “几 何" may not be the original translation of the Latin word "geometriae" (geometry) because the original script used by Xu and Ricci Matteo was a Latin commentary edition titled Euclidis Elementorun Libri XV, in which the word "geometriae" does not appear [4]. “几何” was frequently used in traditional Chinese classics. In general, it is equal to the interrogative word or phrase such as "when," "what time," "how much," etc. In the Biography of Confucius, Records of the Historian (史记·孔子世家), Duke Ling, the ruler of the State of Wei, asked Confucius, “How much did you earn when you served in the State of Lu?" (卫灵公问 孔子： “居鲁得禄几何?” ); it means that only a little time is left. In the same manner, in the Short Song Style (短歌行) by Cao Cao, it was written, “Singing and drinking, life passes by so short” (对酒当歌, 人 生几何). Besides these, the term also can be found in ancient Chinese arithmetic works like the Nine Chapters on the Mathematical Art (九章算术). According to these examples, it is understandable that “几 
何," as a concept familiar to the Chinese, is related to magnitude ${ }^{[4]}$. Therefore, it is not only precise but also vivid as the translation of “magnitudus." “几何” has been gradually accepted by the Chinese people due to this, but its scope of meaning had contracted over centuries and nowadays, it only covers the field of geometry.

Nevertheless, a matter worth noting is that a newly-introduced concept should only be domesticated to an appropriate extent to ensure that its original meaning can be entirely reflected in the target language.

\section{Paying attention to the evolution of the concept while trying to make its target and source texts synchronically equivalent}

Modern linguistics attest that languages are dynamic and are always in a changing process. When translating a concept, a translator is supposed to take its meaning changes into account. Only in this way can he or she be able to make an accurate translation. Meaning changes refer to a situation where sometimes the same concept is likely to be retranslated for several times through the historical process. Such retranslation can be exemplified in the case of translating the word "science."

The concept of "science" was introduced to China by Catholic missionaries in the 16th century, but the word used was the Latin word "scientia," meaning "the studies of knowledge" rather than its English counterpart "science." This is because they came from non-English-speaking Catholic countries where Latin was the religious and academic language. When Ricci Matteo was translating western scientific works in cooperation with Xu Guangqi, they picked up “格致” as the translation of "scientia” (hereinafter, referred to as “science”). “格致," a term originating from “understanding things by observing things" (致知在格 物) in the Great Learning, the Book of Rites (礼记·大学) and valued as a kind of methodology for moral training, basically means "observing a specific thing in a thorough manner to acquire a general understanding of the universe with the purpose of enhancing a person's character for the ideal of exercising good governance over a country." Although “格致,” as a Confucian moral discipline, is different from "science" in the perspective of the world, they share something in common: first, they are methodologically similar because both of them emphasize the observation of things; second, both of them value knowledge despite the fact that what they pursue is of two different aspects; third, science at its very beginning was immature and placed under the framework of philosophy as scientific research revolved around only certain disciplines and scholars became familiar to naming it "natural philosophy." Therefore, it was appropriate to translate "science" into “格致." Besides, it is interesting to find that the Latin word "physica" (hereinafter, referred to as "physics") was also translated into “格致." Given that physics had been the core of scientific studies and many other disciplines had not matured before the 19th century, such a translation had not been ambiguous against the translation of "science," which was also “格致."

However, the rapid development of science since the late 16th century, which had been accelerated especially since the discovery of electromagnetic inductivity in 1831, led to the eventual formation of the modern scientific system in the early 20th century and the close connection between science and technology since the late 19th century. If “格致” is used continuously, it would be difficult for it to reflect the status of scientific development, and it would be likely to be ambiguous against the translation of "physics," which just signifies a discipline under the modern scientific system; moreover, semantically speaking, “格致” only reflects the methodological implication of science but fails to sum up the fact that natural science is a union of disciplines, dealing with nature and the principles behind it. Therefore, it is necessary to replace “格致” with another phrase for the translation of "science."

In 1903, when translating the Studies of Sociology by Spenser, a British sociologist, Yan Fu borrowed the word “科学” from the Japanese, which is the Japanese translation of "science" by the Japanese thinker, Nishi Amane, and used it as the Chinese translation. Such a translation was agreed to by Liang Qichao and had gradually grown in popularity from then on. Since the founding of the Republic of China in 1912, “格 
致” has been out of the public sight, while “科学” has been generally accepted. Generally speaking, it reflects the trend of scientific development in the modern times although it still has some defects in terms of the failure to reflect the original meaning of "science," which is the "studies of knowledge."

\section{Conclusion}

History and experiences deduce that translation is a complicated thinking and practicing process, which involves a multitude of theories and skills, requiring the balance between the source texts and target readers. It is thus necessary for a translator to consult references as detailed as possible, contemplate and compromise between his or her different translations in a ceaseless effort for a satisfactory translation, especially in translating newly-introduced concepts, which are likely to change the development landscape of a nation. The three viewpoints proposed in this article, which give full consideration to the meaning of newly-introduced concepts, pay attention to the evolution of the concepts, and seek for similar meanings in a nation's traditional classics while respecting cultural linkages, can play a methodological role in translation, as proven by the examples in the three sections above. Furthermore, the three viewpoints can be abstracted into two Chinese idioms: "Thoroughly knowing the history and contemporary, and well mastering the domestic and the foreign” (博古通今、学贯中西). These proposals may be immature with some limitations, thus requiring further improvement. However, it is hoped that they may start a discussion where better opinions on this issue can be offered.

\section{Disclosure statement}

The author declares that there is no conflict of interest.

\section{References}

[1] Nida EA, Taber CR, (eds) 1969, The Theory and Practice of Translation, E. J. Brill, Leiden, 178-179.

[2] Nida EA, (eds) 1964, Toward a Science of Translating, E. J. Brill, Leiden, 156, 243, 166-169.

[3] Wu S, 2006, Foreigner' Rights and Chinese's Levels: Selecting Translation Vs Inheriting or Changing Tradition. Well-Read, 2006(8): 4-11.

[4] Yang Q, Tang F, 2011, The Origin and Development of Geometry. Shanghai Journal of Translators, 2011(3): 74-78. 